\title{
HUBUNGAN ANTARA PENGETAHUAN ADMINISTRASI DAN KOMUNIKASI INTERPERSONAL DENGAN KINERJA KARYAWAN POLITEKNIK NEGERI BENGKALIS
}

\author{
Makmuri 1) \\ Gimin ${ }^{2)}$ \\ Wilson ${ }^{3)}$ \\ 1) Post Graduate Student of Riau University \\ 2) Lecturer of Education Management Study Programme PPs University of Riau \\ ${ }^{3)}$ Lecturer of Education Management Study Programme PPs University of Riau
}

\begin{abstract}
This study aims to find a significant association between knowledge of administration and communication with the employee's performance in the Polytechnic Bengkalis partially or jointly. The hypothesis of this study is a significant relationship between the knowledge of the administration of the employee's performance, there is a significant relationship between interpersonal communication with employee performance and there is a significant correlation between knowledge of administrative and interpersonal communication together with the employee's performance.

The research population is all employees who work at the Polytechnic Bengkalis numbered 58 people. The sample in this study are employees working in State Polytechnic Bengkalis amounted to 51 people. The instrument used for data collection was the questionnaire Likert scale model. To test the hypothesis used correlation and regression analysis.

Results of this research is a significant relationship and positive relationship between Knowledge Administration with Employee Performance in State Polytechnic Bengkalis, there is a significant relationship and the positive between Interpersonal Communication with Employees Performance at the Polytechnic Bengkalis and there is a significant relationship and positive relationship between Knowledge Administration and Interpersonal Communication together with Employee Performance in State Polytechnic Bengkalis.
\end{abstract}

Keywords: Knowledge Administration, Interpersonal Communication and Performance. 


\title{
HUBUNGAN ANTARA PENGETAHUAN ADMINISTRASI DAN KOMUNIKASI INTERPERSONAL DENGAN KINERJA KARYAWAN POLITEKNIK NEGERI BENGKALIS
}

\begin{abstract}
ABSTRAK
Penelitian ini bertujuan untuk mengetahui hubungan signifikan antara pengetahuan administrasi dan komunikasi dengan kinerja karyawan di Politeknik Negeri bengkalis secara parsial maupun bersama-sama. Hipotesis yang diajukan dalam penelitian ini adalah terdapat hubungan yang signifikan antara pengetahuan administrasi dengan kinerja karyawan, terdapat hubungan yang signifikan antara komunikasi interpersonal dengan kinerja karyawan dan terdapat hubungan yang signifikan antara pengetahuan administrasi dan komunikasi interpersonal secara bersama-sama dengan kinerja karyawan.

Populasi penelitian ini adalah seluruh karyawan yang bekerja di Politeknik Negeri Bengkalis berjumlah 58 orang. Sampel dalam penelitian ini adalah karyawan yang bekerja di Politeknik Negeri Bengkalis berjumlah 51 orang. Instrumen yang digunakan untuk pengumpulan data adalah dengan angket model skala Likert. Untuk menguji hipotesis digunakan analisis korelasi dan regresi.

Hasil penelitian ini adalah terdapat hubungan yang signifikan dan positif antara Pengetahuan Administrasi dengan Kinerja Karyawan di Politeknik Negeri Bengkalis, terdapat hubungan yang signifikan dan positif antara Komunikasi Interpersonal dengan Kinerja Karyawan di Politeknik Negeri Bengkalis dan terdapat hubungan yang signifikan dan positif antara Pengetahuan Administrasi dan Komunikasi Interpersonal secara bersama-sama dengan Kinerja Karyawan di Politeknik Negeri Bengkalis.
\end{abstract}

Kata Kunci: Pengetahuan Administrasi; Komunikasi Interpersonal; Kinerja.

\section{PENDAHULUAN}

Karyawan merupakan aset yang sangat berharga yang harus dikelola dengan baik oleh perusahaan agar dapat memberikan kontribusi yang optimal demi tercapainya tujuan perusahaan. Salah satu yang harus diperhatikan adalah bagaimana menjadikan komunikasi dan kompetensi sebagai alat utama bagi anggota organisasi untuk dapat bekerja sama dalam melakukan aktivitas manajemen demi pencapaian tujuan yang telah ditetapkan.

Salah satu unsur Administrasi adalah karyawan dan sistem manajemen yang dilaksanakan pada suatu organisasi, kedua unsur tersebut memiliki peranan yang penting dalam mencapai tujuan organisasi. Oleh karenanya organisasi perlu memiliki sumber daya manusia yang handal, demikian pula harus ditunjang oleh suatu sistem manajemen yang kooperatip dan akomodatip sebagai komponen yang mempertegas tujuan organisasi, sistem manajemen yang dikembangkan pada instansi-instansi atau lembaga-lembaga pemerintah seringkali disebut birokrasi.

$\begin{array}{ccc}\text { Birokrasi } & \begin{array}{c}\text { merupakan suatu } \\ \text { berperan }\end{array} \\ \text { kegiatan yang }\end{array}$ menyempurnakan, memperlancar proses kerja dan dapat mencegah terjadinya kesimpangsiuran kerja, sehingga pencapaian tujuan organisasi dapat berjalan sesuai dengan waktu yang telah ditetapkan. Birokrasi juga dapat dipahami 
sebagai suatu kewenangan yang berfungsi sebagai suatu alat untuk melaksanakan program-programnya. dengan demikian Birokrasi tidak harus diasosiasikan sebagai suatu proses yang berbelit-belit dan sangat rumit dengan penghamburan biaya dan waktu yang cukup banyak.

Bagian tata usaha lembaga pendidikan mempunyai tugas pokok menyelenggarakan pelayanan administratif ketatausahaan berdasarkan tugas pokok tersebut bagian tata usaha mengharapkan karyawannya memiliki kinerja yang baik, produktif, disiplin dan bertanggung jawab terhadap pekerjaan yang dibebankan, sesuai dengan peraturan kerja yang ditetapkan. Dalam hal ini birokrasi berperan dan menuntun karyawan untuk melaksanakan pekerjaannya sesuai dengan rencana dan sasarannya secara optimal.

Peningkatan kinerja karyawan akan meningkatkan kredibilitas karyawan, karena bagaimanapun juga hal tersebut menempati posisi yang cukup strategis sebagai parameter untuk mengukur kinerja karyawan dalam melaksanakan tugas dan pekerjaannya. Organisasi harus menjamin dipilihnya orang-orang yang tepat, dengan pekerjaan yang tepat disertai dengan kondisi mereka bekerja optimal.

Berdasarkan hasil wawancara peneliti dengan Sekretaris Pimpinan Politeknik Negeri Bengkalis ibu Nursyafni Maria mengatakan bahwa masih banyak kinerja karyawan yang belum optimal hanya sekitar 52\% karyawan mampu menyelesaikan pekerjaannya dengan baik, hal ini dikarenakan karyawan sering terlambat menyelesaikan pekerjaannya, kurang memperhatikan prosedur pekerjaan, kurang dapat bekerja sama dengan rekan kerja yang lain dan kurang memiliki inisiatif dalam bekerja.

Rasa percaya, keyakinan,

keterbukaan, kejujuran, dukungan keamanan, kepuasan, keterlibatan, tingginya harapan merupakan gambaran iklim organisasi yang ideal. Tujuan utama dari komunikasi antara atasan dengan bawahan adalah mengidentifikasi, menciptakan dan menjalin hubungan timbal balik yang menguntungkan antara pimpinan dengan bawahan. Komunikasi yang efektif ditentukan oleh pihak-pihak yang terlibat di dalamnya, yaitu pimpinan dan karyawan. Pimpinan harus dapat memfasilitasi kondisi komunikasi antar pribadi yang efektif. Komunikasi antar pribadi yang efektif meliputi: keterbukaan (openness), empati (empathy), kepositifan (positiveness), dukungan (supportiveness), dan kesetaraan (equality).

Berikut juga dengan pengetahuan administrasi yang dimiliki oleh karyawan. Pengetahuan administrasi akan dapat meningkatkan kinerja karyawan, dimana karyawan lebih terampil dan memiliki pengetahuan yang baik dalam menjalankan pekerjaannya. Administrasi dalam bidang pendidikan juga sangat diharapkan dapat menjalankan proses pelaksanaan manajemen yang baik dalam suatu organisasi, sehingga pelaksana pendidikan seperti dosen dan mahasiswa merasa terbantu. Karyawan Politeknik Negeri Bengkalis selaku administrasi kurang dapat mengelola administrasi, maka akan sangat menganggu jalannya proses belajar mengajarnya pada suatu instansi pendidikan, maka disinilah peran administrasi itu sangatlah penting.

Berdasarkan uraian di atas, maka peneliti tertarik untuk mengadakan penelitian tesis dengan judul "Hubungan antara pengetahuan administrasi dan komunikasi interpersonal dengan kinerja karyawan Politeknik Negeri Bengkalis".

Dirumuskan masalah dalam penelitian ini adalah :

1. Apakah ada hubungan yang signifikan antara pengetahuan administrasi 
dengan kinerja karyawan di Politeknik Negeri Bengkalis?

2. Apakah ada hubungan yang signifikan antara komunikasi interpersonal dengan kinerja karyawan di Politeknik Negeri Bengkalis?

3. Apakah ada hubungan yang signifikan antara pengetahuan administrasi dan komunikasi interpersonal secara bersama-sama dengan kinerja karyawan di Politeknik Negeri Bengkalis?

\section{Tinjauan Pustaka}

Menurut Stephen P. Robbins, kinerja merupakan hasil evaluasi terhadap pekerjaan yang telah dilakukan dibandingkan dengan kriteria yang telah ditetapkan bersama. Menurut Rudianto bahwa penilaian kinerja adalah penentuan secara periodik efektifitas operasional suatu organisasi, bagian organisasi dan karyawannya berdasarkan sasaran, standar dan kriteria yang telah ditetapkan sebelumnya.

Kinerja menurut Kadri adalah perilaku seseorang dalam menyelesaikan pekerjaannya yang memberi kontribusi bagi pencapaian tujuan organisasi. Kemudian Kadri menjelaskan bahwa faktor yang mempengaruhi kinerja yaitu Persiapan Melakukan Pekerjaan, Proses Pekerjaan, Menyelesaikan Pekerjaan dan Tanggung Jawab Kerja. Berdasarkan berbagai pendapat dan pandangan para ahli di atas, dapat disintesiskan bahwa kinerja adalah perilaku seseorang atau sekelompok orang dalam suatu organisasi dalam menyelesaikan pekerjaannya yang memberi kontribusi bagi pencapaian tujuan organisasi. Selanjutnya penelitian ini menggunakan indikator kinerja yang meliputi Persiapan Melakukan Pekerjaan, Proses Pekerjaan, Menyelesaikan Pekerjaan dan Tanggung Jawab Kerja.

Menurut FIP-UPI, Administrasi ialah keseluruhan proses yang mempergunakan dan mengikutsertakan semua sumber potensi yang tersedia dan yang sesuai, baik personal maupun material, dalam usaha untuk mencapai bersama suatu tujuan secara efektif dan efisien. Sedangkan menurut Hendi Haryadi Administrasi dalam arti luas adalah kegiatan kerja sama yang dilakukan sekelompok orang berdasarkan pembagian kerja sebagaimana ditentukan dalam struktur dengan mendayagunakan sumberdaya untuk mencapai tujuan secara efektif dan efisien.

Berdasarkan berbagai pendapat dan pandangan para ahli di atas, dapat disintesiskan bahwa pengetahuan administrasi adalah apa yang diketahui dalam proses yang mempergunakan semua sumber potensi yang tersedia dan yang sesuai, baik personal maupun material, dalam usaha untuk mencapai bersama suatu tujuan secara efektif dan efisien. Selanjutnya penelitian ini menggunakan indikator pengetahuan administrasi yang meliputi Organisasi, Manajemen, Komunikasi, Kepegawaian, Keuangan, Perbekalan, Tata usaha dan Hubungan Masyarakat.

Komunikasi interpersonal menurut Hardjana adalah "interaksi tatap muka antar dua atau beberapa orang, dimana pengirim dapat menyampaikan pesan secara langsung, dan penerima pesan dapat menerima dan menanggapi secara langsung pula." Dan Menurut Arni Muhammad Komunikasi interpersonal adalah proses pertukaran informasi di antara seseorang dengan paling kurang seorang lainnya atau biasanya di antara dua orang yang dapat langsung diketahui balikannya.

Josep A. De Vito (dalam Thoha) mengemukakan komunikasi interpersonal bisa efektif apabila ada: 1) keterbukaan, keinginan untuk terbuka dimaksudkan agar diri masing-masing tidak tertutup di dalam menerima informasi dan berkeinginan untuk menyampaikan informasi dari dirinya dengan lawan bicaranya, 2) empati, dimaksudkan untuk 
merasakan sebagai mana yang dirasakan oleh orang lain suatu perasaan bersama perasaan orang lain yakni, mencoba merasakan dalam cara yang sama dengan perasaan orang lain, 3) dukungan, adakalanya terucapkan dan adakalanya tidak terucapkan. Dukungan yang tidak terucapkan seperti anggukan, kerdipan mata, senyum, tidaklah mempunyai nilai yang negatif, melainkan dapat merupakan aspek positif dari komunikasi, dan 4) kesamaan, merupakan karakteristik yang teristimewa, karena kenyataannya manusia ini tidak ada yang sama. Akan tetapi jika komunikasi mereka menginginkan efektif, hendaknya diketahui kesamaan-kesamaan kepribadian diantara mereka.

\section{METODOLOGI PENELITIAN}

Metode yang digunakan dalam penelitian ini adalah metode survey dengan teknik korelasional. Dimaksudkan dengan metode survey adalah cara pengumpulan data dari sejumlah unit atau individu. Alat pengumpulan data dalam penelitian ini adalah angket (kuesioner). Angket yang disebarkan berisikan pernyataan yang terkait tiga variabel, variabel bebas Pengetahuan Administrasi (X1) dan Komunikasi Interpersonal (X2). Sedangkan variabel terikat yaitu, tentang Kinerja (Y).

Populasi penelitian ini adalah seluruh karyawan yang bekerja di Politeknik Negeri Bengkalis berjumlah 58 orang. Sampel dalam penelitian ini adalah karyawan yang bekerja di Politeknik Negeri Bengkalis berjumlah 51 orang.

Instrumen yang digunakan untuk pengumpulan data adalah dengan angket model skala Likert. Untuk menguji hipotesis digunakan analisis korelasi dan regresi.

\section{HASIL PENELITIAN DAN PEMBAHASAN}

Secara berturut-turut mengenai deskriptif data dari masing-masing variabel, pengujian persyaratan analisis, pengujian hipotesis, dan pembahasan.

1. Deskripsi Data

a. Pengetahuan Administrasi Para Karyawan di Politeknik Negeri Bengkalis (X1).

Kondisi Pengetahuan

Administrasi para karyawan saat ini adalah tinggi berdasarkan hasil penelitian, dimana Pengetahuan Administrasi dengan jumlah terbanyak pada kategori sebesar $51,0 \%$ dan diikuti terbanyak kedua $31,4 \%$ dengan kategori sangat tinggi, ini menjelaskan bahwa pengetahuan Administrasi pada para karyawan Politeknik Negeri Bengkalis adalah baik.

b. Komunikasi Interpersonal Para Karyawan di Politeknik Negeri Bengkalis (X2).

Kondisi komunikasi interpersonal para karyawan saat ini adalah baik berdasarkan hasil penelitian, dimana komunikasi interpersonal dengan jumlah terbanyak pada kategori sebesar $54,9 \%$ dan diikuti terbanyak kedua $35,3 \%$ dengan kategori cukup baik, ini menjelaskan bahwa komunikasi interpersonal pada para karyawan Politeknik Negeri Bengkalis adalah baik.

c. Kinerja Para Karyawan di Politeknik Negeri Bengkalis (Y)

Kondisi Kinerja Karyawan para karyawan saat ini adalah baik berdasarkan hasil penelitian, dimana Kinerja Karyawan dengan jumlah terbanyak pada kategori sebesar 54,9\% dan diikuti terbanyak kedua 35,3\% dengan kategori cukup baik, ini menjelaskan bahwa Kinerja pada para karyawan Politeknik Negeri Bengkalis adalah baik.

2. Pengujian Persyaratan Analisis

a. Uji Asumsi Normalitas

Dari hasil pengujian di atas ternyata $\mathrm{L}_{\text {hitung }}>\mathrm{L}_{\text {tabel }}$ hal ini berarti bahwa residual regresi $\mathrm{X}_{1}$ dengan $\mathrm{Y}$ dan regresi $\mathrm{X}_{2}$ dengan $\mathrm{Y}$ berdistribusi normal. 
Dengan demikian persyaratan analsisis regresi kedua tidak terpenuhi, dan apabila mengacu pada dalil limit pusat yang menyatakan bahwa sampel yang lebih besar dari 30 mendekati distribusi normal, maka asumsi ini dapat dikatakan terpenuhi.

b. Uji Homogenitas

Pengujian homogenitas data di laksanakan Variansi gabungan, dengan hasil yang didapatkan dimana $\chi^{2}$ hitung $=$ $2,058<\chi_{\text {tabel }}^{2} 5 \%=5,991$, pada $\alpha=0,05$, maka $\mathrm{H}_{0}$ diterima. Dengan kata lain pada tingkat kepercayaan $95 \%$ disimpulkan bahwa ketiga kelompok data berasal dari populasi yang homogen.

3. Pengujian Hipotesis

a. Hubungan antara Pengetahuan Administrasi dengan Kinerja

Berdasarkan hasil $F_{\text {hitung }}$ 38,95 > $F_{\text {tabel }} 7,08$ dengan taraf signifikansi 0,01. Maka $\mathrm{H}_{0}$ ditolak, yang artinya terdapat hubungan yang signifikan dan positif antara Pengetahuan Administrasi dengan Kinerja. Diketahui bahwa $\mathrm{t}$ hitung $=$ $6,260>\mathrm{t}$ tabel $=2,01$ pada taraf alpha $5 \%$ sehingga dapat disimpulkan bahwa koefisien korelasi antara Pengetahuan Administrasi dengan Kinerja adalah sangat signifikan. Dengan demikian, hipotesis yang menyatakan terdapat hubungan positif antara Pengetahuan Administrasi dengan Kinerja teruji kebenarannya.

b. Hubungan antara Komunikasi interpersonal dengan Kinerja

Berdasarkan hasil F-hitung 37,32 $>$ F-tabel 7,08 dengan taraf signifikansi 0,01. Maka $\mathrm{H}_{0}$ ditolak, yang artinya terdapat hubungan yang positif Komunikasi interpersonal dengan Kinerja. Diketahui bahwa $\mathrm{t}$ hitung $=$ $6,118>\mathrm{t}$ tabel= 2,01 sehingga dapat disimpulkan bahwa koefisien korelasi antara Komunikasi interpersonal dengan Kinerja adalah sangat signifikan. Dengan demikian, hipotesis yang menyatakan terdapat hubungan positif antara Komunikasi interpersonal dengan Kinerja teruji kebenarannya.

c. Hubungan Pengetahuan Administrasi dan Komunikasi interpersonal secara bersama-sama dengan Kinerja

Berdasarkan hasil dari $F_{\text {hitung }}$ $(30,382)>F_{\text {tabel }}(3,19)$, Maka $\mathrm{H}_{0}$ ditolak yang menjelaskan bahwa Pengetahuan Administrasi (X1) dan Komunikasi interpersonal (X2) secara bersama-sama mempunyai hubungan yang signifikan dengan Kinerja (Y). Selain itu persamaan regresi

$\hat{Y}=52,166+0,624 \mathrm{X}_{1}+0,423 \mathrm{X}_{2}$ sangat signifikan. Ini berarti bahwa setiap peningkatan satu satuan skor Pengetahuan Administrasi dan Komunikasi interpersonal secara bersama-sama dapat meningkatkan skor Kinerja masingmasing 0,624 dan 0,423 pada konstanta 52,166 .

Hasil perhitungan koefisien determinasi adalah 0,559 atau 55,9\% yang berarti bahwa sebesar $55,9 \%$ variasi variabel Kinerja dalam persamaan regresi ganda dapat dijelaskan oleh Pengetahuan Administrasi dan Komunikasi interpersonal secara bersama-sama melalui persamaan tersebut. Faktor pengetahuan administrasi dan komunikasi interpersonal dalam penelitian ini terbukti secara bersama-sama (simultan) memberikan kontribusi yang sangat signifikan dalam mempengaruhi Kinerja sebesar $55,9 \%$, sedangkan sisanya $44,1 \%$ yang bisa saja dipengaruhi oleh faktor lain di luar penelitian.

\section{SIMPULAN DAN SARAN}

Hasil penelitian ini adalah terdapat hubungan yang signifikan dan positif antara Pengetahuan Administrasi dengan Kinerja Karyawan di Politeknik Negeri Bengkalis, terdapat hubungan yang signifikan dan positif antara Komunikasi Interpersonal dengan Kinerja Karyawan di Politeknik Negeri Bengkalis 
dan terdapat hubungan yang signifikan dan positif antara Pengetahuan Administrasi dan Komunikasi Interpersonal secara bersama-sama dengan Kinerja Karyawan di Politeknik Negeri Bengkalis.

Berdasarkan temuan penelitian ini, maka peneliti mengemukakan beberapa saran sebagai rekomendasi kepada berbagai pihak sebagai berikut :

1. Bagi seluruh karyawan di Politeknik Negeri Bengkalis, Pengetahuan Administrasi memberikan dampak positif terhadap Kinerja sehingga perlu memperhatikan seluruh persoalan terkait dengan Pengetahuan Administrasi para karyawan. Diantara yang dirasa kurang diperhatikan oleh para instansi adalah cara berkomunikasi yang ada, dilihat dari pengetahuan administrasi indikator komunikasi menjadi kurang diantara indikator yang lain.

2. Bagi karyawan di Politeknik Negeri Bengkalis, Komunikasi Interpersonal jelas memberikan dampak besar terhadap Kinerja. Diantara yang dirasa kurang diperhatikan oleh para karyawan adalah karyawan kurang dapat berusaha menghargai pendapat orang lain.

3. Bagi instansi di Politeknik Negeri Bengkalis, diharapkan memperhatikan karyawan, dimana karyawan merasa menyelesaikan beban kerja tidak sesuai dengan apa yang karyawan ketahui. Sehingga dengan memperhatikan beban kerja karyawan, diharapkan kerja karyawan optimal.

\section{DAFTAR PUSTAKA}

Abizar. (1998). Komunikasi Organisasi. Jakarta : Depdikbud Dirjen Dikti Proyek Pengembangan Lembaga Tenaga Kependidikan.
Abdul Ghani Abdullah, Rahman Abd. Aziz. (2009). Mengurus Tingkah Laku. Pelajar. Kuala Lumpur : PTS Professional.

Agus M. Hardjana. (2003). Komunikasi Intarapersonal dan Interpersonal. Yogyakarta : Kanisius.

Alo Liliweri. (2002). Makna Budaya dalam Komunikasi Antarbudaya. Yogyakarta : LKIS Yogyakarta.

Ana Susana. (2007). Kontribusi pengetahuan administrasi dan kepemimpinan kepala madrasah terhadap motivasi kerja guru MTsN di Kabupaten Kediri.

Andry Mochamad Ramdan. (2011). Pengaruh Efektivitas Komunikasi Antarpribadi Terhadap Kinerja (Survei Terhadap Pegawai Negeri Sipil di Organisasi Perangkat Daerah Dinas Peternakan Provinsi Jawa Barat)

Anwar Prabu Mangkunegara. (2004). Manajemen sumber daya manusia perusahaan. Bandung : PT Remaja rosdakarya.

Arni Muhammad. (2009). Komunikasi Organisasi. Jakarta : PT. Bumi Aksara.

Aswathappa. Sadhna Dash. (2008). International Human Resource Management Text and Cases. New Delhi : Tata McGraw-Hill.

Badri Munir Sukoco. (2007). Manajemen Administrasi Perkantoran Modern. Jakarta. Erlangga.

Christina Lia Uripni. Untung Sujianto, Tatik Indrawati. (2003). Komunikasi 
Kebidanan. Jakarta : Buku Kedokteran EGC.

Effendi, O.U. (1993). Psikologi Manajemen \& Administrasi. Bandung : PT Mandar Maju.

Farida Hanun, (2010). Hubungan Komunikasi Interpersonal dan Pengetahuan Manajemen dengan Kepemimpinan Kepala Sekolah (Survey di Madrasah Tsanawiyah/MTs di Kota Bekasi).

Handoko. (1995). Manajemen Personalia dan Sumber Daya Manusia, Edisi Kedua. Yogyakarta: BPFE. 